\title{
EVALUASI KETAHANAN TERHADAP PENYAKIT KUDIS DAN PRODUKSI BEBERAPA KULTIVAR UBIJALAR
}

\author{
Eko Agus Martanto ${ }^{1}$, Adelin Tanati ${ }^{1}$, \& Samen Baan ${ }^{2}$ \\ ${ }^{1}$ Laboratorium Hama Penyakit Tanaman, Fakultas Pertanian, Universitas Papua \\ ${ }^{2}$ Laboratorium Tanah, Fakultas Pertanian, Universitas Papua \\ Jl. Gunung Salju, Amban, Manokwari, Papua Barat 98314 \\ E-mail: e_a_martanto@yahoo.com
}

\begin{abstract}
Evaluation of scab disease resistance and production on sweet potato cultivars. This study was aimed to determine the resistance of local sweet potato cultivars to scab disease in West Papua and the cultivar production. Research was carried out for 6.5 months starting in April 2014. Evaluation of resistance of local sweet potato cultivars and production was designed using a randomized complete block design (RCBD) with three replications. The treatment consists of six local cultivars, namely Mouwebsi, Kuyage-2, Bonsasarai, Inanwatan-4, Wonembai, and Abomourow. There was no inoculation treatment on the field because Papua was endemic region to the scab disease. Data analysis was performed using analysis of variance (ANOVA), followed by DMRT test at level of $95 \%$. Cultivars tested had different responses to the long tendrils of parameters and number of branches. The intensity of the disease in Bonsasarai cultivars was 31.7\% (moderately resistant), while in Mouwebsi was $13.75 \%$, Wonembai $8.33 \%$, Kuyage- $20.42 \%$, Abomourow and Inanwatan-4, $0 \%$ categorized as resistant cultivars. The tuber weight of Abomourow (4.55 ton/ha) was higher than that of Mouwebsi (3.80 ton/ha), Wonembai (3.62 ton/ha), Bonsasarai (2.28 ton/ha), and Inanwatan-4 (1.12 ton/ha).
\end{abstract}

Key words: production, resistance, scab, sweet potatoes

\begin{abstract}
ABSTRAK
Evaluasi ketahanan terhadap penyakit kudis dan produksi beberapa kultivar ubijalar. Penelitian ini bertujuan untuk mengetahui ketahanan kultivar ubijalar lokal terhadap penyakit kudis di Papua Barat dan produksinya. Penelitian dilakukan selama 6,5 bulan dimulai sejak bulan April 2014. Evaluasi ketahanan beberapa kultivar ubijalar lokal dan produksinya dirancang dengan menggunakan rancangan acak kelompok yang perlakuannya diulang tiga kali. Perlakuan terdiri dari enam kultivar ubijalar lokal antara lain Mouwebsi, Kuyage-2, Bonsasarai, Inanwatan-4, Wonembai, dan Abomourow. Tidak ada perlakuan inokulasi di lapangan karena Papua merupakan daerah endemik penyakit kudis. Data dianalisis dengan menggunakan analisis varian, jika perlakuan berbeda nyata, dilanjutkan dengan uji DMRT pada tingkat kepercayaan 95\%. Penelitian menunjukkan bahwa setiap kultivar yang dicoba mempunyai tanggapan yang berbeda pada parameter panjang sulur dan jumlah cabang. Panjang sulur dan jumlah cabang meningkat hingga pengamatan ketiga, pada pengamatan keempat ada yang menurun dan ada yang meningkat. Intensitas penyakit kultivar Bonsasarai sebesar 31,7\% dikategorikan kultivar agak tahan, sementara intensitas penyakit kultivar Mouwebsi 13,75\%, Wonembai 8,33\%, Kuyage-2 0,42\%, Inanwatan-4 dan Abomourow, 0\% dikategorikan kultivar tahan. Bobot umbi kultivar Abomourow 4,55 ton/ha lebih tinggi daripada kultivar Mouwebsi 3,80 ton/ ha, Wonembai 3,62 ton/ha, Bonsasarai 2,28 ton/ha dan Inanwatan-4 1,12 ton/ha.
\end{abstract}

Kata kunci: ketahanan, penyakit kudis, produksi, ubijalar

\section{PENDAHULUAN}

Ubijalar (Ipomoea batatas (L.) Lamb.) merupakan salah satu sumber pangan yang cukup potensial dalam mengatasi ketergantungan terhadap beras (Amir, 1988). Selain itu ubijalar juga menjadi tanaman pangan strategis dalam pengembangan industri bahan makanan (Roosda et al., 2013).
Papua mempunyai potensi persediaan bahan pangan lokal yang sangat besar, terutama ubi-ubian sebagai makanan pokok. Kurang lebih $60 \%$ penduduk menanam ubijalar dan memanfaatkannya sebagai makanan pokok, terutama mereka yang tinggal di daerah Pegunungan Arfak di Kabupaten Manokwari, serta di sekitar danau Wisel di Kabupaten Paniai dan Lembah Baliem di Kabupaten Jayawijaya (Samori et al., 1998). 
Jumlah penduduk Papua kurang lebih 2,2 juta jiwa dengan pertumbuhan penduduk sebesar $3,14 \%$ per tahun. Jumlah penduduk yang terus bertambah mengakibatkan kebutuhan terhadap pangan meningkat. Ubijalar diharapkan dapat menjadi salah satu substitusi pangan non beras terhadap pertumbuhan dan perkembangan jumlah penduduk yang semakin meningkat (Ayomi \& Mampioper, 2008).

Secara garis besar ubijalar dapat dimanfaatkan untuk keperluan bahan pangan, pakan ternak dan bahan industri. Sebagian besar ubijalar digunakan untuk konsumsi, baik sebagai makanan pokok maupun sebagai makanan sampingan. Selain mengandung pati dan gula, ubijalar juga mengandung mineral dan vitamin yang tinggi misalnya zat besi dan betakaroten. Betakaroten banyak dijumpai pada umbi yang berwarna kuning yang sangat membantu dalam penanggulangan kekurangan vitamin A pada anak-anak. Menurut Amir (1990), konsumsi ubijalar yang paling besar ada di daerah Irian jaya dengan $169,2 \mathrm{~kg} / \mathrm{kapita} / \mathrm{tahun}$, diikuti Nusa Tenggara 32,2 kg/ kapita/tahun, sedang di Jawa hanya 9,2 kg/kapita/tahun.

Di Indonesia ubijalar menduduki posisi keempat setelah padi, jagung, dan ubi kayu sebagai bahan pangan. Berdasarkan perolehan kalori ubijalar mengandung 27,9 g karbohidrat, $1,8 \mathrm{~g}$ protein, $0,7 \mathrm{~g}$ lemak dan $123 \mathrm{~g}$ kalori. Kandungan protein dan mineral daun ubijalar cukup tinggi dan sangat baik untuk sayuran (Wargiono, 1980).

Produktivitas ubijalar yang ditanam petani di Papua Barat masih sangat rendah, yaitu 10,30 ton/ha (BPS, 2009). Sementara potensi produktivitas nasional dapat mencapai 20-40 ton/ha (BPS, 2012). Rendahnya produktivitas tersebut disebabkan oleh penerapan teknik budidaya yang minim, tingkat kesuburan tanah yang memang rendah dan infeksi penyakit kudis.

Penyakit kudis merupakan penyakit utama pada tanaman ubijalar. Penyebaran penyakit kudis dijumpai pada hampir semua negara yang membudidayakan tanaman ubijalar antara lain adalah Malaysia, Jepang, Indonesia, Meksiko, dan Brazil (Semangun, 1991). Kerugian yang ditimbulkan pada tanaman yang terinfeksi penyakit kudis berupa penurunan produksi umbi 20-50\% pada klon ubijalar yang rentan (Ramsey et al., 1988).

Berbagai kultivar ubijalar lokal telah ditemukan dengan berbagai keunggulan yang berbeda, seperti berdaya hasil tinggi, tetapi rentan terhadap serangan penyakit kudis. Berdasarkan permasalahan di atas maka penelitian ubijalar untuk mengetahui ketahanan dan produksi yang dihasilkan masih sangat relevan untuk dilakukan. Penelitian ini bertujuan untuk mengetahui ketahanan beberapa kultivar ubijalar lokal terhadap penyakit kudis di Papua Barat dan produksi yang dihasilkan.

\section{METODE PENELITIAN}

Tempat dan Waktu. Penelitian dilaksanakan di Satuan Pemukiman (SP) II Prafi Kabupaten Manokwari, yang dilaksanakan mulai bulan April sampai dengan bulan Oktober 2014.

Perbanyakan Setek Ubijalar. Enam kultivar ubijalar masing-masing ditanam pada petakan tanah seluas $4 \mathrm{x}$ $4 \mathrm{~m}$, setiap kultivar ditanam 30 setek pucuk. Setek kultivar ubijalar diperoleh dari PSUS (Pusat Studi Ubiubian dan Sagu) Universitas Negeri Papua. Kultivar yang diperbanyak tersebut antara lain ubijalar kultivar Mouwebsi, Kuyage-2, Bonsasarai, Inanwatan-4, Wonembai, dan Abomourow. Perbanyakan ini perlu waktu 3 bulan, diharapkan dalam waktu tersebut diperoleh sekitar 200 setek pucuk untuk keperluan tanam di lapangan.

Uji Ketahanan dan Produksi Kultivar Ubijalar. Percobaan ini dilakukan dengan menggunakan rancangan acak kelompok (RAK) dengan 3 ulangan. Perlakuan terdiri atas 6 kultivar lokal, yaitu Mouwebsi, Kuyage-2, Bonsasarai, Inanwatan-4, Wonembai, dan Abomourow sehingga diperoleh 18 satuan percobaan. Percobaan dilakukan selama 3,5 bulan, dan tiap satuan percobaan berupa petak dengan ukuran 2 x $3 \mathrm{~m}$. Selama penelitian tidak dilakukan inokulasi patogen karena Papua merupakan daerah endemik penyakit kudis ubijalar.

Parameter yang diamati meliputi panjang sulur, jumlah cabang, jumlah umbi per tanaman, bobot umbi per tanaman, bobot umbi per petak, dan intensitas penyakit kudis. Parameter diamati 4 minggu setelah tanam, diulang sebanyak 4 kali dengan selang pengamatan 3 minggu. Intensitas penyakit dihitung dengan persamaan sebagai berikut:

$$
I P=\frac{\sum\left(n_{i} \times v_{i}\right)}{N \times V} \times 100 \%
$$

dengan:

IP = Intensitas Penyakit

ni = Banyaknya tanaman dari kategori serangan

vi $=$ Nilai skala dari tiap kategori serangan

$\mathrm{N}=$ Jumlah tanaman yang diamati

$\mathrm{V}=$ Nilai skala tertinggi

Kategori serangan yang dipakai adalah menurut Zuraida et al. (1992) yang dimodifikasi sebagai berikut: $0=$ Sulur sehat, tidak ada infeksi

$1=$ Bercak pada daun, tangkai daun dan sulur $>0-20 \%$ 
$2=$ Bercak pada daun, tangkai daun dan sulur $>20-40 \%$

$3=$ Bercak pada daun, tangkai daun dan sulur $>40-60 \%$

$4=$ Bercak pada daun, tangkai daun dan sulur $>60-80 \%$

$5=$ Bercak pada daun, tangkai daun dan sulur $>80 \%$

Berdasarkan hasil perhitungan intensitas penyakit, Martanto (2004) kemudian mengelompokkan ke dalam tingkat ketahanan sebagai berikut:

$0-20 \%=$ Tahan

$\geq 20-40 \%=$ Agak tahan

$\geq 40-60 \%=$ Agak rentan

$\geq 40-100 \%=$ Rentan

Analisis Data. Analisis data dilakukan dengan menggunakan Analisis Varians (ANOVA), apabila perlakuan berpengaruh nyata maka dilanjutkan dengan DMRT pada taraf $95 \%$.

\section{HASIL DAN PEMBAHASAN}

Panjang Sulur. Hasil analisis menunjukkan bahwa panjang sulur kultivar yang diamati berbeda nyata pada pengamatan pertama sampai pengamatan terakhir (ke4). Pada pengamatan pertama sampai ketiga, sulur yang terpanjang pada kultivar Inanwatan-4 (V4) dan yang terpendek pada kultivar Wonembai (V5). Pada pengamatan terakhir (ke-4), sulur terpanjang pada kultivar Mouwebsi (V1) sebesar 336,9 cm, sedang panjang sulur terpendek tetap pada kultivar Wonembai sebesar 151,27 cm (Tabel 1).

Jumlah Cabang. Hasil analisis menunjukkan bahwa jumlah cabang kultivar yang diamati tidak berbeda nyata pada pengamatan pertama, kemudian berbeda nyata pada pengamatan kedua sampai pengamatan terakhir (ke-4). Pada pengamatan kedua jumlah cabang kultivar Bonsasarai $(8,87)$ berbeda dengan kultivar Mouwebsi
$(5,07)$, dan Kuyage-2 (5,37). Pada pengamatan ketiga terjadi penambahan dan penurunan jumlah cabang pada setiap kultivar yang dicoba. Pada pengamatan ke-4, jumlah cabang kultivar Kuyage-2 $(9,43)$ berbeda nyata dengan jumlah cabang kultivar Inanwatan-4 $(6,27)$, Bonsasarai $(7,07)$, Wonembai $(5,00)$ dan Abomourow $(5,53)$ (Tabel 2).

Intensitas Penyakit Kudis. Gejala penyakit kudis dapat terlihat pada daun, tulang daun dan daun. Pada daun yang terinfeksi (terutama pada tulang daun) tampak bercak yang berwarna lembayung, kemudian menjadi kuning, coklat kekuningan, coklat kemerahan dan akhirnya menjadi coklat kehitaman. Pada batang yang terinfeksi tampak bercak warna coklat. Bercak dapat meluas dan akan bersatu dengan bercak yang lain. Hasil pengamatan menunjukkan bahwa pada pengamatan pertama dan kedua gejala penyakit kudis belum ditemukan pada semua kultivar yang dicoba. Pada pengamatan ketiga, gejala penyakit kudis hanya dijumpai pada kultivar Bonsasarai dengan intensitas penyakit sebesar $0,83 \%$. Pada pengamatan keempat, intensitas penyakit kultivar Bonsasarai menjadi 31,7\% lebih tinggi dibanding kultivar Mouwebsi (13,75\%), Wonembai $(8,33 \%)$ dan Kuyage-2 $(0,42 \%)$. Pada pengamatan keempat ini masih ada kultivar yang belum ditemukan gejala penyakit kudis yaitu kultivar Inanwatan-4 dan Abomourow (Tabel 3). Gejala penyakit kudis beberapa kultivar yang dicoba dapat dilihat pada Gambar 1.

Jumlah Umbi Per Tanaman, Bobot Umbi Per Tanaman dan Bobot Umbi Per Petak Kultivar Ubijalar. Hasil analisis menunjukkan bahwa ada perbedaan yang nyata pada jumlah umbi per tanaman, bobot umbi per tanaman dan bobot umbi per petak dari kultivar yang dicoba. Jumlah umbi per tanaman yang paling banyak dijumpai pada kultivar Wonembai $(3,57)$

Tabel 1. Panjang sulur kultivar ubijalar yang diamati

\begin{tabular}{lccll}
\hline \multirow{2}{*}{ Perlakuan } & \multicolumn{4}{c}{ Panjang sulur $(\mathrm{cm})$ pada pengamatan ke.... } \\
\cline { 2 - 5 } & $\mathrm{I}$ & $\mathrm{II}$ & $\mathrm{III}$ & $\mathrm{IV}$ \\
\hline V1 (Mouwebsi) & $104,36 \mathrm{~b}$ & $168,87 \mathrm{bc}$ & $252,60 \mathrm{bc}$ & $336,90 \mathrm{a}$ \\
V2 (Kuyage-2) & $113,00 \mathrm{ab}$ & $191,30 \mathrm{~b}$ & $191,30 \mathrm{bcd}$ & $203,77 \mathrm{~cd}$ \\
V3 (Bonsasarai) & $133,67 \mathrm{a}$ & $182,97 \mathrm{bc}$ & $284,63 \mathrm{ab}$ & $272,30 \mathrm{~b}$ \\
V4 (Inanwatan-4) & $115,70 \mathrm{ab}$ & $230,17 \mathrm{a}$ & $368,50 \mathrm{a}$ & $247,10 \mathrm{bc}$ \\
V5 (Wonembai) & $52,67 \mathrm{c}$ & $84,13 \mathrm{~d}$ & $109,83 \mathrm{~d}$ & $151,27 \mathrm{~d}$ \\
V6 (Abomourow) & $97,23 \mathrm{~b}$ & $162,53 \mathrm{c}$ & $156,23 \mathrm{~cd}$ & $163,30 \mathrm{~d}$ \\
\hline
\end{tabular}

Angka-angka yang diikuti dengan huruf sama pada kolom yang sama tidak berbeda nyata berdasarkan Uji Jarak Berganda Duncan pada aras 5\%. 
Tabel 2. Jumlah cabang kultivar ubijalar yang diamati

\begin{tabular}{lcccc}
\hline \multirow{2}{*}{ Perlakuan } & \multicolumn{4}{c}{ Jumlah cabang pada pengamatan ke.... } \\
\cline { 2 - 5 } & I & II & III & IV \\
\hline V1 (Mouwebsi) & 4,23 & $5,07 \mathrm{~b}$ & $6,37 \mathrm{ab}$ & $7,90 \mathrm{ab}$ \\
V2 (Kuyage-2) & 3,72 & $5,37 \mathrm{~b}$ & $6,60 \mathrm{ab}$ & $9,43 \mathrm{a}$ \\
V3 (Bonsasarai) & 3,35 & $8,87 \mathrm{a}$ & $6,13 \mathrm{ab}$ & $7,07 \mathrm{bc}$ \\
V4 (Inanwatan-4) & 3,47 & $7,50 \mathrm{ab}$ & $6,37 \mathrm{ab}$ & $6,27 \mathrm{bc}$ \\
V5 (Wonembai) & 4,10 & $7,27 \mathrm{ab}$ & $9,90 \mathrm{a}$ & $5,00 \mathrm{c}$ \\
V6 (Abomourow) & 4,23 & $7,47 \mathrm{ab}$ & $5,00 \mathrm{~b}$ & $5,53 \mathrm{c}$ \\
\hline
\end{tabular}

Angka-angka yang diikuti dengan huruf sama pada kolom yang sama tidak berbeda nyata berdasarkan Uji Jarak Berganda Duncan pada aras 5\%.

Tabel 3. Intensitas penyakit kultivar ubijalar yang diamati

\begin{tabular}{llllc}
\hline \multirow{2}{*}{ Perlakuan } & \multicolumn{4}{c}{ Intensitas penyakit (\%) pada pengamatan ke.... } \\
\cline { 2 - 5 } & I & II & III & IV \\
\hline V1 (Mouwebsi) & 0 & 0 & 0 & $13,75 \mathrm{ab}$ \\
V2 (Kuyage-2) & 0 & 0 & 0 & $0,42 \mathrm{~b}$ \\
V3 (Bonsasarai) & 0 & 0 & 0,83 & $31,70 \mathrm{a}$ \\
V4 (Inanwatan-4) & 0 & 0 & 0 & $0,00 \mathrm{~b}$ \\
V5 (Wonembai) & 0 & 0 & 0 & $8,33 \mathrm{ab}$ \\
V6 (Abomourow) & 0 & 0 & 0 & $0,00 \mathrm{~b}$ \\
\hline
\end{tabular}

Angka-angka yang diikuti dengan huruf sama pada kolom yang sama tidak berbeda nyata berdasarkan Uji Jarak Berganda Duncan pada aras 5\%.

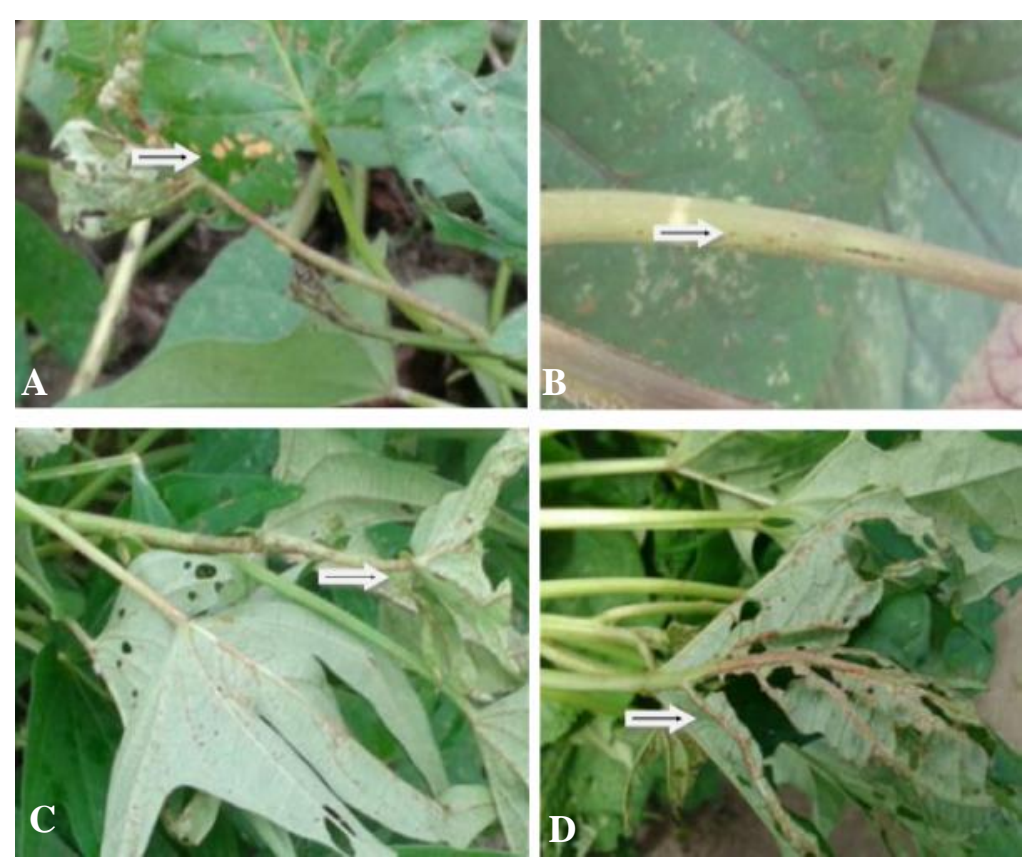

Gambar 1. Gejala penyakit kudis pada beberapa kultivar ubijalar. (A) Kultivar Mouwebsi (V1); (B) Kultivar Kuyage2 (V2); (C) Kultivar Bonsasarai (V3); (D) Kultivar Wonembai (V5) 
dan yang tidak menghasilkan umbi adalah kultivar Kuyage-2 (0). Berdasarkan bobot umbi per tanaman maka bobot umbi yang paling berat ada pada kultivar Abomourow (341,7 g/tanaman), di bawahnya adalah kultivar Wonembai $(285,47 \mathrm{~g} / \mathrm{tanaman})$ dan yang paling rendah adalah kultivar Kuyage-2 (0 g/tanaman). Bobot umbi per petak yang paling besar adalah kultivar Abomourow (2,73 kg/petak), kemudian di bawahnya kultivar Wonembai $(2,28 \mathrm{~kg} /$ petak) dan yang paling rendah/tidak menghasilkan adalah kultivar Kuyage-2 (0 $\mathrm{kg} /$ petak) (Tabel 4).

Ubijalar yang diteliti ditanam pada tanah gembur dan dibuat guludan serta menggunakan setek pucuk sehingga pertumbuhan vegetatif dan pembentukan umbinya maksimal. Hendroatmodjo (1990) menyatakan bahwa penggunaan setek pucuk antara $25-30 \mathrm{~cm}$ akan mempercepat perkembangan umbi daripada setek tengah atau pangkal. Wargiono (1980) menyatakan bahwa ubijalar yang tidak ditanam di atas guludan menyebabkan hasil umbi kecil-kecil karena batang menjalar ke segala jurusan dan setiap akar pada buku yang berhubungan dengan tanah membentuk umbi yang kecil-kecil.

Panjang sulur dan jumlah cabang merupakan variabel penting dalam mengamati pertumbuhan tanaman karena berhubungan dengan jumlah daun yang terbentuk. Kultivar Mouwebsi mempunyai panjang sulur tertinggi dan kultivar Abomourow dengan panjang sulur terendah. Hal ini karena setiap kultivar memiliki karakteristik yang berbeda terhadap panjang sulur tanaman ubijalar. Kebanyakan kultivar mempunyai batang menjalar yang cukup panjang tetapi ada juga kultivar yang tajuknya merumpun, batangnya lebih pendek dan tumbuh lebih tegak (Fajriani et al., 2012).

Panjang sulur dan jumlah cabang meningkat hingga pengamatan ketiga, kemudian pada pengamatan keempat ada yang menurun dan ada yang meningkat.
Hal ini dipengaruhi oleh perubahan tanaman dari fase vegetatif ke fase generatif dimana pada fase generatif pertumbuhan panjang sulur pada tanaman berhenti. Sari (2008) menyatakan bahwa pada fase pembentukan dan pengisian umbi berlangsung cepat maka pertumbuhan batang dan daun berkurang. Hal ini diperkuat oleh pendapat Hahn \& Hozyo (1996) yang mengatakan bahwa ada hubungan terbalik antara pertumbuhan daun dan umbi. Semakin besar umbi, produksi cabang dan daun menurun dan secara bertahap berhenti.

Pada variabel intensitas penyakit didapatkan bahwa pada pengamatan pertama dan kedua semua kultivar belum menunjukkan gejala penyakit kudis, baru pada pengamatan ketiga ada gejala di kultivar Bonsasarai dengan intensitas penyakit yang masih kecil $(0,83 \%)$. Lambatnya gejala yang terjadi karena selama penelitian memang tidak dilakukan inokulasi patogen penyebab penyakit kudis karena Papua merupakan daerah endemik penyakit kudis. Pada pengamatan keempat, kultivar Bonsasarai menunjukkan kultivar yang paling peka karena intensitas penyakitnya yang paling besar, sementara kultivar Inanwatan-4 dan Abomourow belum menunjukkan gejala. Berdasarkan besarnya intensitas penyakit yang terjadi, ketahanan kultivar Bonsasarai dikategorikan agak tahan, sementara lima kultivar lainnya termasuk kultivar yang tahan terhadap penyakit kudis.

Pada pengamatan terakir, daun kultivar Bonsasarai, Wonembai dan Mouwebsi yang terinfeksi tampak berkerut dan mengecil, dan jumlah bercak di tulang daun pada sisi bawah juga banyak. Bercak dapat meluas dan akan bersatu dengan bercak yang lain, sehingga pada tangkai daun yang terinfeksi seolah-olah tertutup bercak tersebut. Kenampakan gejala pada kultivar Kuyage-2 berbeda dengan gejala yang terjadi pada ketiga kultivar yang lainnnya. Daun yang terinfeksi tidak berkerut dan mengecil, gejala tampak kecil dan halus pada tangkai daun (Gambar 1). Penyakit kudis

Tabel 4. Jumlah umbi per tanaman, bobot umbi per tanaman dan bobot umbi per petak ubijalar yang dicoba

\begin{tabular}{lccc}
\hline \multicolumn{1}{c}{ Perlakuan } & Jumlah umbi per tanaman & Bobot umbi per tanaman $(\mathrm{g})$ & Bobot umbi per petak $(\mathrm{kg})$ \\
\hline V1 (Mouwebsi) & $2,27 \mathrm{~b}$ & $285,47 \mathrm{ab}$ & $2,28 \mathrm{ab}$ \\
V2 (Kuyage-2) & $0,00 \mathrm{c}$ & $0,00 \mathrm{~d}$ & $0,00 \mathrm{~d}$ \\
V3 (Bonsasarai) & $2,63 \mathrm{~b}$ & $170,87 \mathrm{bc}$ & $1,37 \mathrm{bc}$ \\
V4 (Inanwatan-4) & $2,40 \mathrm{~b}$ & $83,37 \mathrm{~cd}$ & $0,67 \mathrm{~cd}$ \\
V5 (Wonembai) & $3,57 \mathrm{a}$ & $270,87 \mathrm{ab}$ & $2,17 \mathrm{ab}$ \\
V6 (Abomourow) & $2,30 \mathrm{~b}$ & $341,70 \mathrm{a}$ & $2,73 \mathrm{a}$ \\
\hline
\end{tabular}

Angka-angka yang diikuti dengan huruf sama pada kolom yang sama tidak berbeda nyata berdasarkan Uji Jarak Berganda Duncan pada aras 5\%. 
dapat menurunkan produksi ubijalar. Di Indonesia produksi umbi klon ubijalar rentan yang terserang penyakit kudis mengalami penurunan hingga 30\% (Amir, 1988).

Perbedaan serangan tiap kultivar ini selain didukung oleh ketahanan yang berbeda, juga disebabkan perbedaan jumlah cabang tiap kultivar. Walaupun jumlah cabang kultivar Bonsasarai tidak sebanyak kultivar Kuyage-2 tetapi daun yang terbentuk hampir sama banyak dan lebat sehingga menyebabkan iklim mikro di sekitar tanaman mendukung perkembangan patogen. Hal ini sesuai pendapat Zadoks \& Schein (1979) yang menyatakan bahwa iklim mikro merupakan syarat penting untuk siklus infeksi, dari melekatnya spora sampai penyebaran spora.

Jumlah umbi per tanaman dari kultivar yang diteliti bervariasi, dari kultivar yang tidak menghasilkan sama sekali (Kuyage-2) sampai kultivar Wonembai dengan jumlah umbi yang paling banyak $(3,57)$. Semua petak kultivar Kuyage-2 tidak ada yang menghasilkan umbi walaupun pertumbuhan vegetatif tanamannya baik seperti kelima kultivar yang lainnya. Tidak dihasilkannya umbi pada kultivar ini karena (1) kultivar Kuyage-2 berasal dari Wamena yang merupakan dataran tinggi, yang biasanya panen pada umur tanaman 5-6 bulan. Lokasi penelitian ada pada dataran rendah dan waktu panen dilakukan pada umur tanaman 3,5 bulan. Berdasarkan ketinggian tempat yang berbeda dan waktu panen yang lebih cepat menyebabkan saat panen belum terbentuk umbi, (2) ubijalar kultivar Kuyage-2 dalam pemanfaatannya diduga bukan diambil umbinya tetapi hanya diambil daunnya sebagai sayur.

Jumlah umbi per tanaman kultivar Wonembai paling banyak tetapi bobot umbi per tanaman bukan yang yang paling besar dan hanya menduduki peringkat kedua setelah kultivar Abomourow walaupun jumlah umbi pertanamannya lebih rendah daripada kultivar Wonembai. Hal ini membuktikan bahwa umbi kultivar Abomourow lebih besar daripada kultivar Wonembai. Pertumbuhan umbi tergantung dari laju pertumbuhan yang direfleksikan melalui produksi bahan kering umbi. Hal ini sesuai dengan pendapat Wargiono dan Tuherkih (1986) dalam Legiawati (1995) yang menyatakan bahwa pertumbuhan umbi tergantung pada aktivitas fotosintesis atau laju asimilasi.

Bobot umbi per tanaman merepresentasikan bobot umbi per petak. Bobot umbi kultivar Abomourow $2,73 \mathrm{~kg} /$ petak (4,55 ton/ha) lebih tinggi daripada kultivar Wonembai 2,28 kg/petak (3,80 ton/ha), Mouwebsi 2,17 $\mathrm{kg} /$ petak (3,62 ton/ha), Bonsasarai 1,37 kg/petak (2,28 ton/ha) dan Inanawatan-4 0,67 kg/petak (1,12 ton/ha).

\section{SIMPULAN}

Setiap kultivar yang dicoba mempunyai tanggapan yang berbeda pada parameter panjang sulur dan jumlah cabang. Panjang sulur dan jumlah cabang meningkat hingga pengamatan ketiga, pada pengamatan keempat ada yang menurun dan ada yang meningkat.Intensitas penyakit kultivar Bonsasarai sebesar 31,7\% dikategorikan kultivar agak tahan, sementara intensitas penyakit kultivar Mouwebsi 13,75\%, Wonembai 8,33\%, Kuyage-2 0,42\%, Inanwatan-4 dan Abomourow 0\% dikategorikan kultivar tahan. Bobot umbi kultivar Abomourow 4,55 ton/ha lebih tinggi daripada kultivar Mouwebsi 3,80 ton/ha, Wonembai 3,62 ton/ha, Bonsasarai 2,28 ton/ha dan Inanawatan-4 1,12 ton/ha.

\section{SANWACANA}

Ucapan terimakasih penulis sampaikan kepada pemerintah melalui DP2M Ditjen DIKTI atas dana yang diberikan pada tahun 2014 sehingga penelitian ini dapat dilakukan.

\section{DAFTAR PUSTAKA}

Amir M. 1988. Masalah penyakit kudis (Elsino $\ddot{e}$ batatas) pada ubijalar dan cara pengendaliannya. Dalam: Paiki FA \& Matanubun H (Eds.). Prosiding Seminar Ubi-ubian Irian Jaya. pp. 153-162. Manokwari, 27-29 Juli 1988.

Amir M. 1990. Studies of sweet potato (E. batatas) in Indonesia. The International Workshop on Integrated Management of Diseases and Pest of Tuber Crops. pp. 1-5. Bhubaneswar, India. October 21-27, 1990

Ayomi C \& Mampioper DA. 2008. Konsumsi-panganlokal-di-papua-rendah. http://tabloidjubi. wordpress.com_2008/04/28. Diakses tanggal 24 Nopember 2013.

BPS. 2009. Kabupaten Manokwari Dalam Angka. Badan Pusat Statistik Kabupaten Manokwari.

BPS. 2012. Harvest Area, Production and Yield of Potatoes. www.bps.go.id. Diakses tanggal 24 Nopember 2013.

Fajriani N, Boer D, Suliartini NWS, Sadirmantara IGR, \& Suaib. 2012. Heritabilitas sifat agronomi penting beberapa klon ubijalar lokal yang dibudidayakan dapat menurunkan produksi ubijalar. Di 
Indonesia, di desa-desa pinggiran kota Kendari. Berkala Penel. Agron. 1(2): 156-163.

Hahn SK \& Hozyo Y. 1996. Ubi Manis. Dalam: Goldsworthy PR \& NM Fisher. Fisiologi Tanaman Budidaya Tropik. Gadjah Mada University Press, Yogyakarta.

Hendroatmodjo KH. 1990. Distribusi bahan kering dan hasil tiga kultivar ubijalar berasal dari stek yang berbeda. Penel. Palawija 5(1): 48-59.

Legiawati RI. 1995. Pertumbuhan dan perkembangan tanaman ubijalar sebagai kriteria penetapan umur panen optimum. Skripsi. Institut Pertanian Bogor, Bogor.

Martanto EA. 2004. Interaksi Inang Patogen pada Penyakit Kudis Ubijalar (Elsinoe batatas). Disertasi. Universitas Gadjah Mada, Yogyakarta.

Ramsey MD, Vawdrey LL, \& Hardy J. 1988. Scab (Sphaceloma batatas) a new disease of sweet potato in Australia; fungicide and cultivar evaluation. Aust. J. Exper. Agric. 28(1): 137141.

Roosda AA, Waluyo B, Wibisono T, \& Kurniawan A. 2013. Peran nyata hortikultura, agronomi dan pemuliaan terhadap ketahanan pangan. Seminar Nasional 3 in One Hortikultura, Agronomi dan Pemuliaan. pp. 7-13, Universitas Brawijaya, Malang 21 Agustus 2013.
Samori P, Paiki FA, \& La Musadi. 1998. Kajian terhadap penyakit kudis Elsinoe batatas pada berbagai kultivar dan sistem budidaya ubijalar di Lembah Baliem Wamena. Hyphere, J. Ilmiah Ubi-ubian dan Sagu 3(1): 1-7.

Sari FCW. 2008. Analisis Pertumbuhan Ubijalar (Ipomea batatas L.) dan Tanaman Nenas (Ananas comosus (L.) Merr) dalam Sistem Tumpang Sari. Skripsi. Universitas Sebelas Maret, Surakarta.

Semangun H. 1991. Penyakit-Penyakit Tanaman Pangan di Indonesia. Gadjah Mada University Press, Yogyakarta.

Wargiono J. 1980. Ubijalar dan Cara Bercocok Tanamnya. Lembaga Pusat Penelitian Pertanian. Bogor.

Zuraida N, Bari A, Wattimenna CA, Amir M, \& Soenaryo R. 1992. Pengaruh penanaman campuran klon ubijalar terhadap penyakit kudis dan hasil. Penel. Pert. 12(3): 119-121.

Zadoks JS \& Schein RD. 1979. Epidemiology and Plant Diseases Management. Oxford University Press, New York. 